\title{
DEFINITIONS ESTABLISHING THE SCOPE OF HARMONIZATION IN THE FIELD OF CONSUMER CREDITS. COMPARATIVE ASPECTS
}

\author{
Mariana Rodica ȚîRLEA \\ "Dimitrie Cantemir" Christian University Bucharest, Romania \\ rodicatirlea10@yahoo.ro
}

\begin{abstract}
The sphere of consumer loans implies protection, knowledge, anticipatory regulations, flexibility, adaptability leading to the elaboration of a modern, clear legislation and an efficient internal credit market. Clear, explicit and clear legislation contributes to increasing the trust of customers, consumers and effectively to their protection. The European Directive states that: "in order to ensure consumer confidence, it is important that the market provides them with a sufficient degree of protection" [1]. In this way, the demand and supply of loans can be achieved in optimal conditions, both for professionals who offer loans and for credit consumers. A sufficient degree of protection ensures the confidence of credit consumers. In this sense, the concept of complete harmonization, from the perspective of the European Directive is seen as necessary in order to achieve a high level of interest of consumers and professionals. Legislation easily understood by the parties involved in credit agreements, does not leave room for some interpretations. For this reason, we appreciate the fact that the presentation of the definitions, the transparency in the knowledge of their meaning represent one of the important measures of protection of the customers consuming loans.
\end{abstract}

Keywords: Harmonization, full harmonization, consumers, credit consumers, definitions of application of credit harmonization

Full harmonization requires "a high and equivalent level of protection of their interests and the creation of a genuine internal market. Accordingly, Member States should not be allowed to maintain or introduce provisions of national law other than those laid down in this Directive. "[1]. From this perspective, such a limitation in the case of harmonized provisions should not apply. Such a situation allows states to introduce national provisions and / or maintain existing ones. In the case of loans contracted for an indefinite period, the Directive provides for "the right to set a minimum period which must run between the time when the creditor requests repayment and the day on which the loan must be repaid" [1]. Harmonization involves understanding the meaning of terms, definitions specific to the lending sector. We note that the European directive refers to certain types of loans that would not be limited to those subject to it. This is the case for the following type of credit agreements:

1. amounts less than EUR 200;

2. amounts greater than EUR 75 000;

3. linked credits;

4. credits which partially benefit from the requirements of the European Directive;

5. services that the consumer benefits from in the idea that the amount related to the loan is reimbursed by him in installments for the entire contracted time; 
6. credits for the supply of goods in the event that the credit consumer pays the credit in installments during the period of supply of those goods;

7. may differ considerably, from the point of view of the interests of the Contracting Parties involved, as well as the manner and conduct of transactions;

8. debit cards with deferred payment;

9. granting loans with real estate guarantees;

10. debit cards with deferred payment, which provide for a repayment period of three months and insignificant costs.

The harmonization of the national policies of the Republic of Moldova in the field of consumer protection was a "need to harmonize the principles and ways of achieving the objectives in the field of consumer protection with those applied in the European Union and internationally, as a result of transposing or harmonizing a series of directives by the legal system of the Republic of Moldova" [3].

\section{Relevance of definitions in practice and in informing consumers in advance of concluding credit agreements}

In the Republic of Moldova, at the level of 2020, the organic law was amended: Law LP202 / 2013 of 12.07.2013, on consumer credit contracts, Published on: 06.09.2013 in the Official Gazette no. 191-197 art. 619. Modified LP23 of 27.02.20, MO87-93 / 20.03.20 art.112; in force on: 20.06.20. Article 5. of the law, [2], is entitled: Precontractual information that presupposes:

1. for the beginning the receipt of an offer and the expiration of 15 days until the date on which the contract will be started;

2 . the contract must be printed on paper, contain the same font size, be clearly written and legible;

3. the mandatory information that must be contained in the contract must be:

4. specifying the type of credit;

5. the name of the professional (creditor); the name of the credit intermediary; the registered office of the professional (creditor); the registered office of the credit intermediary - assuming that it is; the name of the professional's representative; the name of the credit intermediary involved;

6 . the total amount of the contracted credit; the use of credit;

7. the time period related to the loan;

8. for loans that are set up as deferred payments under the assumption of a service or for a good, the contract will contain, as the case may be, information on the price of the services or, as the case may be, of the good or goods that are the subject of that credit agreement;

9. the system of applying the interest rate in concrete conditions;

10. issues concerning APR (annual percentage rate);

Annex no. 2 of the law stipulates "it must indicate that the application of other withdrawal mechanisms for this type of credit agreement may result in the application of a higher effective annual interest rate" [2].

10. the amount, number and frequency of payments they want to be made by the consumer and, where appropriate, the order in which the payments will be allocated, for repayment, to the various outstanding balances fixed at different interest rates on the credit

11. number and frequency of payments they want to be made by the consumer and, where appropriate, the order in which the payments will be allocated, for repayment, to the various outstanding balances fixed at different interest rates on the credit;

13. where applicable, the costs of administering one or more accounts which record both payment transactions and credit withdrawals, unless the opening of an account is optional, the costs of using a means of payment, both for payment transactions as well as for withdrawals from credit, any other costs resulting from the credit agreement, as well as the conditions under which these costs may be modified; 
14. where applicable, information on the consumer's obligation to pay notarial fees at the conclusion of the credit agreement;

15. obligations relating to the conclusion of a contract relating to an ancillary service relating to a credit agreement, in particular an insurance policy, if the obtaining of credit or obtaining credit in accordance with the terms and conditions presented is conditional;

16. the interest rate applicable to overdue installments, the measures to adjust it and, where appropriate, the amount of penalties for non-payment;

16) a warning to the consumer about the consequences of non-payment; n) where applicable, the requested guarantees;

17) the right of revocation;
18) aspects of advance payment;

19) free customer information;

20) Prior to concluding the contract, the client has the right to receive a draft credit agreement to analyze and study it;

21) the pre-contractual period for the creditor, of 15 calendar days, is mandatory.

The definition of the concepts is required quickly from the consumer information period. It is another formula for their protection in contracts concluded with professionals. The definition and explanation of the concepts regarding consumer credit agreements is the objective of Article 3 of the Law [2]. We present their significance in table number 1 :

Table 1. Main concepts

\begin{tabular}{|c|c|c|}
\hline No. & Concepts & The significance of concepts \\
\hline 1. & $\begin{array}{l}\text { Consumer } \\
\text { creditworthiness }\end{array}$ & $\begin{array}{l}\text { ability to pay at maturity of the credit rate and of the accessories } \\
\text { materialized in: interest and costs related to the contracted credit; }\end{array}$ \\
\hline 2. & Consumer & $\begin{array}{l}\text { represents an individual who either intends or even uses loans that are } \\
\text { not related to his entrepreneurial activity; }\end{array}$ \\
\hline 3. & Creditor & $\begin{array}{l}\text { is a legal representative who, according to his legal object of activity, } \\
\text { grants credits; }\end{array}$ \\
\hline 4. & $\begin{array}{l}\text { The credit } \\
\text { agreement }\end{array}$ & $\begin{array}{l}\text { Proof in written form regarding the credit and the conditions under } \\
\text { which it was granted as well as the rights and obligations of the parties } \\
\text { to the contract; }\end{array}$ \\
\hline 5. & $\begin{array}{l}\text { Bound / united } \\
\text { credit agreement }\end{array}$ & $\begin{array}{l}\text { credit agreement used in financing conditions for a contract that aims to } \\
\text { provide either services or goods for the entire contracted period; }\end{array}$ \\
\hline 6. & $\begin{array}{l}\text { The cost elements } \\
\text { of credit }\end{array}$ & represents all the costs incurred by the client in obtaining the loan \\
\hline 7. & $\begin{array}{l}\text { „ effective annual } \\
\text { interest/Annual } \\
\text { Percentage rate } \\
\text { (APR)'[2] }\end{array}$ & $\begin{array}{l}\text { the percentage ratio between the total cost of the loan and the total } \\
\text { amount of the loan; }\end{array}$ \\
\hline 8. & $\begin{array}{l}\text { "Account } \\
\text { overdraft" }\end{array}$ & $\begin{array}{l}\text { represents a credit facility granted to a client in the event that there is an } \\
\text { excess over the current balance; }\end{array}$ \\
\hline 9. & $\begin{array}{l}\text { "Overdraft" } \\
\text { facility" }\end{array}$ & $\begin{array}{l}\text { an agreed credit facility that intervenes when the current account } \\
\text { balance is exceeded and is tacitly accepted by the customer }\end{array}$ \\
\hline 10. & $\begin{array}{l}\text { Consumption of } \\
\text { payments under } \\
\text { the consumer } \\
\text { credit agreement }\end{array}$ & $\begin{array}{l}\text { the loan repayment schedule which represents those aspects concerning } \\
\text { the maturity dates of the loan and the amounts due at the due dates; }\end{array}$ \\
\hline 11 & $\begin{array}{l}\text { Credit } \\
\text { intermediary }\end{array}$ & $\begin{array}{l}\text { individual or legal person who does not act as a creditor and who, } \\
\text { during the exercise of his commercial or professional activity, in } \\
\text { exchange for a fee, which may take pecuniary form or any other agreed } \\
\text { form of payment, carries out at least one of the following activities: }\end{array}$ \\
\hline
\end{tabular}




\begin{tabular}{|c|c|c|}
\hline 12 & $\begin{array}{l}\text { Credit interest } \\
\text { rate }\end{array}$ & $\begin{array}{l}\text { interest rate expressed as a fixed or floating percentage applied } \\
\text { annually to the amount drawn from the loan; }\end{array}$ \\
\hline 13 & $\begin{array}{l}\text { Fixed interest rate } \\
\text { on the loan }\end{array}$ & $\begin{array}{l}\text { the agreement of the parties, in the credit agreement, on an interest rate } \\
\text { related to the credit for the entire duration of the credit agreement or on } \\
\text { several interest rates related to the credit for partial terms, applying } \\
\text { exclusively an established fixed percentage. If not all credit interest } \\
\text { rates are fixed in the credit agreement, it is considered that the credit } \\
\text { interest rate is fixed only for partial terms for which the credit interest } \\
\text { rates are set exclusively by a specific fixed percentage agreed at the } \\
\text { time of concluding the credit contract; }\end{array}$ \\
\hline 14 & $\begin{array}{l}\text { Accessory } \\
\text { services }\end{array}$ & $\begin{array}{l}\text { services arising in connection with the granting, administration and } \\
\text { settlement of the debtor's claim; }\end{array}$ \\
\hline 15 & Durable support & $\begin{array}{l}\text { is represented by the existence on electronic and / or letric support of } \\
\text { the information regarding the credit and its development during the } \\
\text { whole contracted period in time }\end{array}$ \\
\hline 16 & $\begin{array}{l}\text { the total value of } \\
\text { the loan }\end{array}$ & the total amount of credit; \\
\hline 17 & $\begin{array}{l}\text { "the total amount } \\
\text { payable by the } \\
\text { consumer'[2] }\end{array}$ & the amount of the loan plus the accessories related to the loan \\
\hline
\end{tabular}

Source: Author based on Article 3. LP23 of 27.02.20, MO87-93 / 20.03.20 art.112; in force 20.06.20 from the Republic of Moldova

We note on the basis of the analysis performed that, compared to the concepts defined in the Community directive, in the law LP23 of 27.02.20, the following concepts are also defined:

1. consumer creditworthiness, which has the meaning of "the consumer's ability to repay, at maturity, the credit under the credit agreement, including interest and related costs" [2];

2. ancillary services, which are defined as "services which arise in connection with the granting, administration and settlement of a claim";[2]

3." consumer credit payments, which means information on the amounts and dates (periods) of payment to the consumer under the consumer credit agreement, which is coordinated between the creditor and the consumer and is an integral part of the credit agreement for the consumer" [2].

\section{Conclusions}

The practice has demonstrated the existence of disparities in the bank credit market. These inaccuracies create significant internal barriers that affect traders and consumers and have led to lawsuits. For these reasons, the harmonization of key regulatory issues will support those involved in contractual relations on bank loans. Harmonization aims to protect both professionals and consumers. Clarifying the definitions, as well as knowing their meaning, is very important for the parties involved in bank lending agreements: creditor and consumer. Compared to European directives [1], we notice in the law LP23 of 27.02.20, of the Republic of Moldova that the concepts regarding: consumer creditworthiness, ancillary services, consumption of payments according to the credit agreement for consumers are additionally defined. The European directive does not deal with these concepts in terms of definitions, but these are addressed in the directive and refer to them. Knowledge of the meaning of the concepts is required quickly starting from the pre-contractual information and throughout the credit period.

The clauses of the contract refer only to the object of the contract, no matter how general 
the terms used in it" [4] and are "interpreted to the detriment of the party who formulated them" [4]. We appreciate the fact that this knowledge of the meaning of the concepts, of the terms used in the contractual relations, represents another measure of protection of the customers consuming bank loans.

\section{References List:}

[1] Directive 2008/48/ EC of the European Parliament and of the Council of 23 April 2008 on consumer credit agreements and repealing Council Directive 87/102 / EEC, Official Journal of the European Union, L 133/66

https://eur-lex.europa.eu/legal-content/EN/ALL/?uri=CELEX:32008L0048

[2] Law no. LP202/2013 of 12.07.2013, regarding the credit contracts for consumers Published: 06.09.2013 in the Official Gazette no. 191-197 art. 619 Date of entry into force Modified LP23 of 27.02.20, MO87-93/20.03.20 art.112; in force 20.06.20 of the Republic of Moldova

[3] Băieșu, A., \& Plotnic, O (2014), Consumer protection law ”, CEP USM, ISBN 978-9975-71511-9, page 7

[4] Civil Code of the Republic of Moldova, updated, art, 731 and 732, page, 166

[5] Law no. 187 of 22.07.2016, in force 16.03.2017 of the Republic of Moldova

[6] https://www.legislation.gov.uk/eudr/1993/13/article/2 